\title{
MERETAS MAKNA POST-TRUTH: ANALISIS KONTEKSTUAL HOAKS, EMOSI SOSIAL, DAN POPULISME AGAMA
}

\section{Marz Wera \\ Perhimpunan Mahasiswa Katolik Republik Indonesia}

\begin{abstract}
Post-Truth complete global informations. This phenomenon brings with it three symptoms namely hoax, social emotions and religious populism. The actors use democratic facilities for the purposes of their group's interests. Often anti-demorative. This movement destabilizes the deocratic states with a disinformation strategy through social media to clear procedures. The hallmark of political communication is demagogy. The actor is demagogue. They make vague movements in the name of democracy with an alibi of freedoms of approval. The strategy is increasingly sophisticated along with the era of the media technology revolution while disrupting technology on the life culture of a nation. This paper is a critical notes about the wave of contextual issues that describe our nation's democracy these days.
\end{abstract} KEYWORDS: Post-Truth, hoax, social emotions, religious populism, demagogy, demagogues, technological revolution, social media.

ABSTRAK: Post-Truth sedang jadi gejala mutakhir secara global. Fenomena ini membawa serta tiga gejala yakni hoaks, emosi sosial dan populisme agama. Para aktornya memakai fasilitas demokrasi untuk tujuan-tujuan kepentingan kelompoknya. Kerap anti-demorasi. Gerakan ini mendestabilisasi negara demokrasi dengan strategi disinformasi lewat media sosial untuk menerjang prosedur. Ciri khas komunikasi politiknya adalah demagogi. Aktornya adalah demagog. Mereka melakukan gerakan samar atas 
nama demokrasi dengan alibi kebebasan berpendapat. Strateginya makin canggih bersamaan dengan era revolusi teknologi media sekaligus disrupsi teknologi terhadap budaya hidup suatu bangsa. Tulisan ini merupakan catatan kritis mengenai gelombang isu-isu kontekstual yang mewarnai demokrasi bangsa kita hari-hari ini.

KATA-KATA KUNCI: Post-Truth, hoaks, emosi sosial, populisme agama, demagogi, demagog, revolusi teknologi, media sosial.

\section{Pendahuluan}

Millenium III, abad 21 adalah era self connection. ${ }^{1}$ Interaksi hampir tak terbatas oleh ruang dan waktu. Kita pun masuk dalam masa hidup menakjubkan. Karena kita ikut masuk dalam komunitas warga global yang terintegrasi. Era ini di awali dengan perkembangan teknologi informasi yang kian canggih. Tanda kemajuan ilmu pengetahuan, kebudayaan, dan bahasa.

Kemampuan baru berekspresi dan arus informasi dengan leluasa melahirkan lanskap virtual mahakaya. Bayangkan semua situs yang kita sambangi, semua surel yang kita kirim, dan jutaan kisah yang kita baca secara daring, semua fakta yang ribuan orang jajaki setiap detiknya, dan berjuta cerita rekaan yang kita sanggah kebenarannya. Cobalah untuk membayangkan setiap hubungan yang kita jalin, setiap perjalanan yang kita rencanakan, setiap orang yang kita temui di ruang daring, juga setiap mimpi yang sudah jadi nyata dan mewujud dalam platform digital ini. Seiring meluasnya ruang digital, pemahaman manusia akan hidupnya juga berubah, mulai dari hal remeh sampai pada pertanyaan mendasar yakni tentang jati diri, relasi bahkan keamanan identitas diri. "Semua yang terbatas dan dibatasi dahulu kala, kini berguguran. Aliran baru dan daya cipta manusia mulai bergolak bangkit."'2

Lantas, bagaimana masa depan peradaban bangsa manusia khususnya konteks Indonesia dengan seluk beluk sistem demokrasi yang diliputi oleh dinamika global seiring tren digitalisasi?

Dalam konteks demikian, manusia harus beradaptasi dengan kemajuan tersebut. Proses adaptasi ini membawa manusia sedang menuju mentalitas ilmiah. Karena cara berpikir manusia secara global mulai mengarah pada rasionalitas. Perkembangan kebebasan berpikir memaksa manusia untuk semakin rasional dalam nalar kritisnya sebagai bagian dari integrasi kemajuan teknologi dan rasionalitas publik. Sejalan dengan itu, arus informasi

1. Manusia yang saling terhubung satu sama lain.

2. Eric Schmidt \& Jared Cohen, Era Baru Digital (Jakarta: Kepustakaan Populer Gramedia, 2014), xi-xx. 
berseliweran setiap hari, hampir tak terbendung. Publik pun hidup dalam logika waktu pendek. Yang berarti segala informasi yang datang dan pergi, entah di share atau bukan tidak melalui proses seleksi secara baik. Karena semua butuh kecepatan, sesuatu yang ringkas tanpa mau berpikir panjang dan kritis terhadap kebenaran dan objektivitas berita.

Internet mengizinkan satu miliar bunga mekar, namun sebagian besarnya berbau busuk, mulai dari pikiran iseng para penulis blog, teori konspirasi, hingga penyebar hoaks. Tambahan pula, internet bukan hanya membuat kita makin bodoh, tapi juga lebih kejam. Di dunia maya sebagian dari kita tak ingin menguji informasi, berdiskusi dan berdebat sehat, tapi mengecilkan opini orang lain yang berbeda, menghina, dan menyerang. Anda berkelana sampai menemukan kesimpulan yang Anda tuju. Anda mengklik laman demi pembenaran, dan keliru dalam membedakan jawaban dengan kekuatan argumen. ${ }^{3}$

Era digital adalah era dimana ketakjuban orang bukan lagi soal esensi tapi eksistensi. Orang lebih mengagungkan sesuatu yang punya pesona, genit, sensitif dan manipulasi. Menjawab hal itu, aksesoris dan selebritis adalah dunia khas dari semua gelagat hidup manusia modern. Sesuatu yang kritis akan dihindari karena dinilai kaku dan membosankan. Karena sesuatu yang punya pesona selalu genit dan sensitif untuk menarik perhatian publik. Semua bisa dicapai dengan cepat karena berkat bantuan kemajuan teknologi digital. Pada konteks ini, penulis mengucapkan selamat datang di era Post-Truth. Era yang penuh dengan manipulasi, problem identitas dan kejutan. Intinya, kemasan selalu punya pesona.

Masyarakat abad ini, abad 21 memiliki kecenderungan untuk mudah terpolarisasi akibat arus balik informasi yang hampir tak terpetakan dan tanpa kendali. Dalam arus seperti ini, polarisasi dihiasi politik identitas menjadi pesona yang makin menguat dengan proses yang cukup jelas. Hal ini tak terhindarkan karena gejala Post-Truth menandai adanya benturan peradaban yang memungkinkan terbukannya ruang perebutan atas pengakuan akan identitas kolektif, yang dengan sistematis diamplifikasi secara cepat lewat bantuan teknologi informasi digital, yang juga merenggut sikap kritis dan rasionalitas.

Dalam konteks itu, begitu banyak orang, baik secara individu maupun kelompok mudah terjebak dalam serangan distribusi informasi yang beredar. Di satu sisi mentalitas ilmiah ingin menemukan ruang rasionalitas nalar kritisnya, sebaliknya malah ada perlawanan. Ada orang yang tak lagi percaya pandangan-pandangan lama, berupa bualan mitos karena cara 
berpikir yang maju, tapi ada juga yang malah mengagungkan irasionalitas berpikir yang mana berseliweran cerita mitos. Megalomania di satu sisi, hipokrisi di sisi lain. Sensasi dirayakan, esensi diabaikan. Proses digital menyiapkan panggung untuk itu.

Di sana ada yang terjebak, di sini ada yang mencari sensasi. Ini sering terjadi di Indonesia menyusul derasnya informasi yang dibentengi kecanggihan teknologi. Informasi menjalar bukan untuk menangkap apa yang diharapkan tetapi darimana harapan itu diarahkan kepada publik untuk menghidupkan emosi sosial berupa ujaran kebencian. Kita bisa melihat itu melalui headlines yang menjebak dan punya daya pikat sensasi. Cobalah buka media sosial atau pun media elektronik, judul berita dan isinya ada yang berbeda.Meskipun masih banyak warga bangsa yang belum memahami fenomena ini, sudah menjadi kenyataan bahwa istilah ini merasuk dan masuk dalam percakapan kita sehari-hari. "Ruang publik yang kita huni dewasa ini adalah ruang publik yang amat kuat dipengaruhi oleh media sosial digital."'4

Hoaks bermula dari kurik ini. Sebab, hoaks tidak bisa dihindari seiring perkembangan teknologi yakni penggunaan media sosial oleh masyarakat yang secara individu benar-benar menemukan kebebasannya untuk menyebarkan informasi. Seiring dengan itu, nalar kritis masyarakat dalam mencermati kebenaran justru mengalami kelemahan. Hoaks pada intinya bekerja dengan jeli oleh pembuatnya dalam melihat keinginan atau daya tarik masyarakat terhadap fenomena sosial, budaya, politik, demi meyakini apa keinginan masyarakat. Menurut J A Liorente, fenomena seperti ini menandakan bahwa iklim sosial politik mengabaikan objektivitas dan rasionalitas dengan membiarkan emosi/hasrat memihak pada keyakinan meski fakta memperlihatkan hal yang berbeda. ${ }^{5}$ Yang terjadi dengan era ini adalah keyakinan pribadi lebih dikedepankan daripada logika dan fakta dalam ruang publik.

Dari data Kemenkominfo, sepanjang tahun 2017 ada 800.000 akun palsu yang sering menyebarkan hoaks. Kominfo mengidentifikasi ada 486 hoaks sepanjang April 2019. Jadi, total ada 1.731 hoaks dalam jenjang waktu antara Agustus 2018-April 2019. Hoaks kembali meningkat ketika jelang Pemilu pada 17 April 2019. Pada Agustus 2018 tercatat 25 konten hoaks, naik menjadi 27 konten hoaks pada September 2018. Sementara pada Oktober dan November 2018, beranjak ke angka 53 dan 63, Desember 2018, terus naik di

4. J. Sudarminta, "Agama, Ruang Publik, dan Tantangan Era Pasca-Kebenaran," dalam Meluhurkan Kemanusiaan, ed. F. Wawan Setyadi (Jakarta: Penerbit Buku Kompas, 2018), 158.

5. Haryatmoko, "Mencari Kebijakan di Era Post-Truth: menghadapi hoaks, Emosi sosial, dan Populisme Agama," Majalah Basis, Nomor 05-06, Tahun ke-68, 2019, 28-37. 
angka 75. Bahkan sejak tahun 2016 terus mengalami peningkatan yakni 14 konten hoaks, 2017 meningkat jadi 281, sementara tahun 2018 meningkat jauh menjadi 1440 konten hoaks. ${ }^{6}$

Kasatgas Nusantara, Irjen Pol Gatot Eddy Pramono menyampaikan data penyebaran berita bohong alias hoaks dari akun media sosial asli, semi anonim hingga anonim dari 2017-2018. Sejak pertengahan 2017 hingga Desember 2018, 3.884 konten hoaks dan ujaran kebencian disebar di media sosial. Penyebaran konten hoaks dan ujaran kebencian oleh 643 akun asli, 702 semi anonim dan 2.533 anonim. Jumlah akun anonim meningkat 100 persen di 2018 dibandingkan 2017 yang hanya 733.

Dari ribuan kasus hoaks yang menghiasi kehidupan bangsa kita baik secara daring maupun nyata sepanjang 2016 hingga 2019, penulis menemukan tiga kasus hoaks yang paling menyita perhatian, kegaduhan bahkan mengundang berbagai reaksi spontan publik. Pertama, hoaks mengenai penganiayaan Ratna Sarumpaet yang beredar di Facebook tanggal 2 Oktober 2018 di akun Swary Utami Dewi. Konten tersebut kemudian viral melalui Twitter, diunggah kembali oleh beberapa tokoh politik tanpa melakukan verifikasi kebenarannya. Setelah ramai diperbincangkan, konten hoaks ditanggapi Kepolisian dengan melakukan penyelidikan setelah mendapatkan tiga laporan. Berdasarkan hasil penyelidikan Kepolisian, Direktur Tindak Pidana Umum Polda Metro Jaya Kombes Pol Nico Afinta mengatakan Ratna telah melakukan perjanjian operasi pada 20 September 2018.

Kedua, hoaks mengenai mahasiswa Papua di Surabaya yang dituduh membuang bendera Merah Putih di got depan asrama mereka. Isu ini kemudian disebarkan melalui Whatsapp hingga mengundang emosi publik yang beramai-ramai mengepung asrama mahasiswa Papua. Dalam kasus yang sama makin menguak ketika warga kota Surabaya mendatangi dan menyerang secara membabi buta bersama kelompok aparat keamanan baik itu kepolisian maupun kalangan TNI. Kasus ini juga akhirnya merambat ke beberapa kota besar di Indonesia berupa reaksi balik mahasiswa Papua juga aksi solidaritas bersama dengan melakukan demonstrasi besar-besaran. Karena selain hoaks juga ada ucapan yang tidak pantas bahkan sangat tidak manusiawi dari warga yang saat itu menyerang asrama dengan sebutan

6. KEMKOMINFO, Laporan tahunan 2016-2019, diakses: Senin, 30 September 2019, Pkl. 10.00 WIBhttps://kominfo.go.id/content/detail/16003/siaran-pers-no-17hmkominfo012019-tentang-tahun2018-kominfo-terima-733-aduan-konten-hoaks-yang-disebar-via-whatsapp/0/siaran,https://kominfo. go.id/content/detail/16023/kominfobeberkan-sederet-kasus-hoax-di- whatsapp/0/sorotan_media, diakses: Senin, 30 September 2019, Pkl. 10.00 WIB.

7. polri.go.id, Laporan Kasatgas Nusantara Mabes Polri tahun 2018, http://tribratanews. polri.go.id/?p=428902, diakses: 14 Desember 2019, Pkl. 22.00 WIB https://nasional.okezone.com/ read/2019/01/15/337/2004711/berapa-jumlah-hoaks-ujaran-kebencian-dari-2017-2018-berikut-datanya, diakses: 14 Desember 2019, Pkl.22.00 WIB. 
"monyet" untuk sesama saudara dari Papua. Kasus ini kemudian merambat bahkan hingga kerusuhan di beberapa kota lain di Papua dan banyak fasilitas publik yang rusak karena di bakar massa. Peristiwa ini sampai sekarang mahasiswa Papua sendiri bingung dan tidak tahu soal isu yang disebar, bahkan pihak kepolisian juga belum memberikan penjelasan yang valid soal kebenaran pembuangan bendera tersebut.

Ketiga, kehadiran para buzzer yang berselancar secara virtual dengan bebas tapi sangat sistematis khususnya mengawali masa kampanye menjelang Pemilu 17 April 2019. Para buzzer ini bukan hanya kubu opisisi semata, pihak pemerintah juga punya tim sendiri. Mereka adalah kumpulan pendukung fanatik terhadap tokoh karismatik pilihan politiknya. Sayangnya, isu buzzer ini baru terkuak ke perbincangan publik di akhir bulan september 2019. mereka bekerja berdasarkan sosok berpengaruh atau trend dunia digital menamakanya influencer. Perang antara para buzzer yang terbagi dalam kubu tertentu, merupakan konfirmasi masifnya geliat manipulasi percakapan di media sosial dengan cara kerja sistematis. Menurut Ika Karlina Idris, penggunaan pasukan media sosial atau buzzer ini sebenarnya sudak sangat massif sejak pilkada DKI Jakarta 2017, hanya saja geliatnya ditutupi oleh isu populisme agama. ${ }^{8}$

Fenomena ini persis kebalikannya, bahwa rasionalitas berupa nalar kritis yang merupakan ciri khas mentalitas ilmiah justru terhimpit. Banyak yang berubah sebaliknya kalau soal Indonesia. Mentalitas ilmiah berarti berpegang pada data dan fakta. Sementara perlawanan sebaliknya mengabaikan data dan fakta. Hal ini bisa kita saksikan juga dalam perhelatan lima tahunan yang baru saja kita lewati yakni pemilu serentak 2019 yang ditandai oleh problem identitas, hoaks, aksi saling serang di media sosial, pemisahan "kita" dan "mereka" berbeda, kecemasan, emosi sosial, serta keyakinan agama menjadi laris untuk dijual dalam momen yang sama.

Tanpa sadar, kita sedang memasuki era banalitas penuh kebohongan yang sejak beberapa dekade menyelimuti suasana kebangsaan kita khusunya ruang maya. Konteks demikian, yang kemudian dikenal sebagai era Post-Truth atau Paska Kebenaran. Era dimana, bullshit melampaui dusta. Menurut F Budi Hardiman, fenomena ini adalah disrupsi dalam dunia politik yang sangat politis secara besar-besaran yang kemudian diintensifkan oleh teknologi digital secara masif menjadi suatu prahara. Karena menerpa demokrasi normal yang ingin setia pada rasionalitas, fakta dan kebenaran. Ketika bullshits besar-besaran disajikan kepada publik bagaikan kehebohan hipnotis, publik terkecoh sekaligus dibuat kagum oleh para otokrat dan 
oligarki baru yang berbicara atas nama demokrasi. ${ }^{9}$

Dalam konteks demikian bullshit sebenarnya dipakai sebagai kendaraan untuk mengganti tatanan demokratis yang ada sekaligus mekanisme hukum ikut didistorsikan olehnya. Lebih dari itu, sebenarnya politik Pasca Kebenaran bisa membuka ruang bagi gerakan radikalisme agama ke panggung demokratis. Sekilas mereka tampak demokratis, tetapi sesungguhnya mereka itu otoriter populis yang siap menggunakan apapun, termasuk agama sebagai alat pendongkrak elektabilitas. Narasi-narasi besar yang mereka tuturkan tanpa data yang bisa dipercaya dan retorika ugal-ugalan yang bertentangan dengan akal sehat, sengaja untuk membangkitkan amarah massa terhadap tatanan politis yang ada. Gejala seperti ini mengandung risiko tinggi bagi eksistensi hukum yang berlaku, selama sistem hukum itu lemah. ${ }^{10}$

Hukum sebagai alat pemaksa dan dasar integrasi sosial membuka ruang sekaligus memungkinkan perannya sebagai penata kompleksitas, penyelesai konflik, penjamin akal sehat publik dan sabuk pengaman demokrasi dari kepungan hoaks yang menjadi kekhasan politik pasca kebenaran yang dimediasi secara digital. Post-Truth adalah situasi yang menyebabkan kita mudah terjebak pada badai informasi simpang siur tanpa fakta. Post-Truth pula yang membuat hoaks mudah muncul dan disebarkan tanpa kendali. Media sosial sebagai jembatan baru yang bisa mempersatukan sekaligus memisahkan, mengumpulkan keluarga yang terpisah, serta mempertemukan teman baru.

Begitulah posisi dilematis manusia di era menakjubkan ini. Rasionalitas berpikir manusia seiring sejalan dengan warna warni cerita mitos di ruang publik. Mitos yang bekerja dalam modus kebohongan masif, yakni hoaks. Usaha manusia untuk makin rasional malah terjebak pada irasionalitas. Peradaban justru bergerak mundur menjadi barbar. Kemajuan teknologi membawa ke arah kehancuran dan disintegrasi bangsa. Dalam konteks ini, lahirlah gejala emosi sosial yang mudah mengecoh siapapun untuk melakukan animalitas kepada sesamanya. Ilmu pengetahuan dan teknologi bukan untuk menganugerahkan martabat dan kebebasan subtansial manusia, kesadaran diri, tapi malah menjerat dan memenjarahkan manusia dalam rantai ideologi sisipan dan belenggu fanatisme buta atas nama agama tertentu yakni populisme agama.

Tulisan ini merupakan analisis kontekstual reflektif-filsafati yang secara kritis merefleksikan dinamika demokrasi bangsa Indonesia dalam

9. F Budi Hardiman, "Menemukan Kebenaran Hukum di Era Post-Truth,'Keynote Speaker: Seminar Nasional AFHI, Mataram, 24-27 Juni 2019.

10. Ibid. 
lanskap globalisasi dengan tren digitalisasi konseptual-empiris untuk memperkaya khazanah ilmu pengetahuan. Demikian kontekstualisasi isu dan opini publik yang mewarnai dinamika demokrasi baik dalam negeri maupun secara global menjadi dasar analisis untuk menjelajahi tren digitalisasi yang bergerak maju dengan segala kecanggihannya. Fenomena ini menarik untuk merangsang nalar kritis kita sebagai bagian dari komitmen intelektual para cendekiawan untuk hadir memberikan tanggung jawab moralnya. Mempertegas kedalaman analisis ini, penulis menjadikan tiga isu utama yang cukup dalam negeri sembari menyinggung 3 isu global yang menarik perhatian publik sebagai wahana untuk menjelajahi fenomena Post-Truth dalam membingkai masa depan mentalitas ilmiah manusia Indonesia dengan refleksi pada tiga karakteristik di atas yakni hoaks, emosi sosial dan populisme agama.

\section{Indonesia Hari Ini}

Peradaban bangsa kita sedang mengalami keretakan, baik dari dalam maupun dari luar. Indonesia sedang berada pada posisi dilematis. Kita mengagungkan kebebasan sebagai dalil negara demokrasi, sekaligus mengekalkan ketidakbebasan sebagai persoalan identitas. Dalilnya "'kita" dan "mereka" berbeda. Semua menyuarakan keberagaman sekaligus mengkampanyekan perbedaan.

Kita seperti hidup dalam dua dunia. Republic of hope vs republic of fear. Akal sehat, secara rasional dan kritis tentu memilih republic of hope. Faktanya otoritas kita lebih mencintai untuk memelihara republic offear. Tom Nichols dalam bukunya The Death of Expertise menjelaskan fenomena runtuhnya standar-standar penilaian ilmiah. Euphoria media sosial ditandai dengan ketidakmampuan secara kolektif untuk membedakan antara yang informatif dan yang spekulatif, antara yang proporsional dan yang berlebihan, antara yang mengandung kebohongan dan yang layak dipertimbangkan. ${ }^{11}$

Sebab, kebanyakan orang sibuk dengan apa yang dipikirkan orang lain tentang dirinya sehingga apapun bisa dilakukan untuk menciptakan citra baik dihadapan orang lain. Ralph Keyes mengatakan semakin bertambah dewasa seseorang, akan semakin cekatan tumbuh dalam berbohong. Remaja yang populer adalah pembohong yang lebih baik daripada yang tidak populer. Menurutnya orang cenderung berbohong ketika self-esteem ${ }^{12}$ secara pribadinya terancam. Ini menjadi fenomena sehari-hari. Tuntutan pencitraan diri demi eksistensi inilah yang mendorong orang untuk

11. Nichols, The Death of Expertise, 90.

12. Penghargaan terhadap diri sendiri. 
mudah berbohong. ${ }^{13}$ Haidt menegaskan bahwa kecenderungan berbohong itu menunjukkan bahwa dalam hal politik dan moral, manusia itu pada dasarnya lebih groupish daripada selfish. ${ }^{14}$

Komunikasi antar warga bangsa terjebak dalam hasrat ejek-mengejek: mencari kepuasan dalam kedunguan lawan. Demagogi sebagai busa kalimatnya. Dalam kalimat berbusa, hoaks serta hasutan emosi sosial bertebaran. Demagogi adalah ilmu menyiram angin demi menuai bau, mencari sensasi dalam psikologi massa untuk menikmati kebanggaan diri. Sang tokoh akan mencari penonton demagogis, yakni mereka yang siap menelan angin dan berjuang dengan modal angin. Dengan psikologi inilah politik diwarnai hoaks untuk mengepung publik. Demokrasi kita hari ini ada dalam situasi demikian. ${ }^{15}$

Kebebasan berdemokrasi ada dalam situasi dilematis. Di sana ada ujaran kebencian, di sini ada bualan mitos. Di lingkungan kampung halaman warga begitu tinggi toleransinya, sementara di kota orang sibuk saling serang. Ada yang terusik, ada yang tersakiti. Karena atas nama kebebasan orang mudah menyerang dan menjelekkan sesama warga bangsanya. Kemunafikan tampak pada situasi seperti ini, megalomania menemukan ruang dalam konteks kemunafikan yang demikian.

Sementara itu, dalam kebebasan banyak yang kehilangan arah dan patokan hidup bersama. Ada semacam gejala fanatisme buta terhadap tokoh-tokoh tertentu, mau menunjukkan bahwa masyarakat kita sedang membutuhkan arah dan pegangan bersama. Mungkin pada tataran yang lebih subtil, menurut Nietzsche, demokrasi adalah pegangan baru setelah kematian Tuhan. ${ }^{16}$

Kebebasan dan toleransi yang tidak terkendali bisa berujung kebablasan dan mengakibatkan ingatan masyarakat kian terurai. Situasi kian pelik dan rumit ketika kemajuan teknologi mengantarkan masyarakat kita untuk melompat memuja ideologi konsumeristik, hedonis: pemujaan sekaligus kenikmatan, yang menggelikan adalah pemujaan pada yang kelihatan lebih muda dari usianya. Orang hidup di zaman aksesoris dan selebritis, sehingga mengalami lompatan besar beberapa dekade melampui gelagat zaman. Masyarakat kita tidak terarah dalam pola hidup untuk mengalami setiap

13. Ralph Keyes, The Post-Truth Era: Dishonesty and Deception in Contemporary Life (New York: St. Martin's Press, 2004), 3-5.

14. Jonathan Haidt, The Righteous Mind: Why Good People are Divided by Politic and Religion (New York: Vintage Books, 2012), 97.

15. Rocky Gerung, "Debat Bukan Sabung Ayam," Tempo, 7 Juli 2014, 7.

16. A. Setyo Wibowo, "Kritik Nietzsche Atas Demokrasi: Rezim Setara Tapi Galau Merindukan Identitas," Majalah Basis, No.05-06, Tahun ke-68, 2019, 16. 
jejak kemajuan zaman. Kita selalu melewati beberapa jejak kemajuan, sebab kita selalu gagap dalam menyambut setiap kebaruan.

Iklan-iklan bertebaran dengan tubuh muda, segar, seksi, penuh vitalitas. Orang separo baya dan orangtua mencari cara agar tampak muda. Para ahli makanan dan olahragawan berlomba menawarkan riset untuk memiliki tubuh yang muda. Para ilmuwan mencari teknik ajaib, meneliti "gen pemutar waktu" agar bisa membalik usia demi orang menjadi muda lagi. Masyarakat akhirnya hidup dalam bayangan, "muda adalah surga.."17 Orangtua dan orang dewasa dipaksa oleh situasi demikian untuk tidak bersikap seperti orangtua, tapi harus sejajar dengan remaja ataupun generasi milenial agar bisa berkomunkasi sejajar dengan mereka.

Para pendidik juga mengalami gejolak yang sama, bukan lagi jadi teladan sebagai pendidik yang mendidik melainkan sebagai teman seperjalanan yang sama-sama sedang mencari rute perjalanan. Demokrasi dengan kebebasan dan toleransi yang sangat eksesif memunculkan kedaulatan total kaum muda. Rezim yang demikian akhirnya melahirkan segala sesuatu yang serba instan, panas-panasan, oversensitif, mudah tersinggung, mulut berbusa, norak dan penuh retorika berupa bualan mitos yang gampang dan mudah untuk diserap dan diingat orang.

Demokrasi liberal yang serba toleran menghasilkan generasi muda serba bingung: disatu sisi mereka diidealkan masyarakatnya, disisi lain, mereka tetaplah anak-anak muda yang masih belum paham dengan dunianya, yang masih mencari-cari pegangan akan identitas mereka. Anak-anak muda yang butuh pegangan, namun tak mendapatkannya dari orangtua atau masyarakatnya-menjadi lahan subur untuk dipanen oleh pengkhotbah radikal, para demagog, para Sofis, ${ }^{18}$ kaum tiran. ${ }^{19}$

Kisah manusia yang hidup era ini, adalah kisah manusia budak yang berseliweran segala macam informasi bohong, dimana proses pencarian akan identitas mulai menyeruak, gejala penyatuan tirani satu ide mulai berkumpul, kesatuan gagasan dan konsep mulai menemukan ruangnya, serta keyakinan pada bualan mitos dan retorika para pengkhotbah dan politisi demagog diagungkan di ruang publik. Menurut Setyo Wibowo, manusia budak menyatukan diri berkat sebuah pegangan yang membuatnya merasa

17. Ibid., 17.

18. Sekelompok filsuf yang hidup dan berkarya pada zaman Sokrates. Mereka muncul pada pertengahan hingga akhir abad ke-5 SM. Meskipun sezaman, kaum sofis dipandang sebagai penutup era filsafat pra-sokratik sebab Sokrates akan membawa perubahan besar di dalam filsafat Yunani. Golongan sofis bukanlah suatu mazhab tersendiri, melainkan kaum sofisme dipandang sebagai suatu gerakan dalam bidang intelektual di Yunani saat itu.

19. Pola komunikasi dengan tujuan meminjamkan suaranya pada suara rakyat dan pandai, lihai serta piawai menghasut naluri massa untuk tujuan-tujuan tertentu. 
utuh, merasa benar, di depan masyarakat atau agama yang dilawannya. ${ }^{20}$ Mereka adalah sekelompok orang yang dengan kehendak kuasanya merasa diri mampu mengutuhkan dirinya masing-masing dalam kelompoknya dalam bingkai identitas baru yang diyakini bersama sebagai jalan baru menuju kebenaran sejati.

Kita seperti dikondisikan untuk mengabaikan verifikasi kebenaran yang bersasar pada akal sehat. Beragam bentuk media sosial yang mudah dan gampang diakses oleh setiap individu membuat kebohongan mudah menyelinap melalui kebingungan publik karena ragam informasi. Sisi lain literasi yang lemah, mengakibatkan orang tidak bisa lagi membedakan antara opini, fakta, dan analisis. Di pengujung fenomena ini, keragaman identitas kultural kita mudah terpolarisasi oleh ideologi tempelan yang masuk melalui berbagai macam gerakan samar, bahkan ketegangan dan konflik identitas pun makin menguak.

Dari arah demikian, hoaks hadir menyuburkan polarisasi masyarakat karena meneguhkan keyakinan akan ideologi tertentu dari masing-masing kelompok. Melalui kebohonganlah keyakinan akan ideologi makin tumbuh subur. Seperti apa yang dikatakan oleh Haryatmoko, "mengapa kebohongan itu memikat? Karena pembohong menurut Arendt, berbicara dengan mengikuti logika hoaks yang mau memuaskan keyakinan audiensnya. Hoaks adalah anak kandung Post-Truth." ${ }^{21}$

\section{Karateristik Post-Truth Society}

Post-Truth berkembang pesat dimasyarakat yang sudah diwarnai oleh arus informasi yang mengalami ketidakpuasan dan kekecewaan terhadap politik. Apa yang terjadi dalam Post-Truth adalah relativisasi kebenaran dengan objektivitas data, dramatisasi pesan jauh lebih penting daripada isi pesan itu sendiri. Dalam era Post-Truth, narasi selalu mengalami kemenangan mutlak terhadap data atas fakta yang ada, maka sangat perlu dilakukan fact-checking atau pemeriksaan terhadap suatu fakta. ${ }^{22}$

Istilah itu muncul seperti patahan dalam demokratisasi. Sebetulnya tidak ada kondisi yang begitu cocok untuk mewujudkan ideal-ideal demokrasi, yaitu politik deliberatif, kewarganegaraan inklusif, keadilan sebagai fairness, seperti kondisi kita dewasa ini, ketika ponsel pintar telah memindahkan diskusi-diskusi dari auditorium, forum, kontainer massa,

20. Wibowo, "Kritik Nietzsche," 18.

21. Haryatmoko, "Mencari Kebijakan," 29.

22. Fathul Wahid, Musa Asy'arie, Haryatmoko, "Etika Media Sosial di Era Post-Truth" (Diskusi publik, Jogjakarta, 12 Desember 2018), https://www.youtube.com/watch?v=eF0dieNrSE8, diakses: 10/12/2019 Pkl. 20.00 WIB. 
ke dalam genggaman. Seharusnya inilah saatnya demokrasi ditopang oleh kebenaran dan penalaran publik yang sehat. Akan tetapi, justru persis pada saat ini, ketika akses langsung ke dalam politik dimungkinkan oleh telepon genggam, ideal-ideal demokrasi itu justru luput dari genggaman. ${ }^{23}$

Kita sedang hidup dalam dunia yang membingungkan sekaligus mempesona bagi siapa pun. Mulai dari orangtua hingga segala macam lembaga sedang kehilangan otoritasnya. Orang mengapungkan kebebasan sekaligus mengagungkan toleransi atas kesalahan siapapun dengan alibi negara demokrasi. Dengan argumentasi atas nama hak asasi manusia, orangtua dilarang menghukum anaknya, kurangi aturan publik, sehingga semua orang menerima situasi tersebut menjadi bagian dari kewajiban individu untuk menghargai individu yang lainnya. Tata nilai dan moralitas dalam agama jadi hambar, efeknya banyak orang mengalami disorientasi total, khusus bagi generasi mudah justru tumbuh kembang dalam dunia seperti ini. Takjub sekaligus bingung. Dalam kebingungan, rasionalitas macet.

Padahal kritik yang pedas memerlukan pengetahuan yang dalam. Sinisme yang kejam datang dari logika yang kuat. Dua-duanya kita perlukan untuk menguji pikiran publik agar tak berubah menjadi doktrin, agar panggung publik tak dikuasai para demagog. Kita hendak menumbuhkan demokrasi sebagai forum pikiran. ${ }^{24}$ Tantangannya, kabar bohong yang sudah jauh melampui rasionalitas dan alam bawah sadar publik sehingga mudah terjebak dalam banjir emosi sosial yang berefek pada gerakan populisme berbasis agama tertentu. Agama jadi pesona dan primadona dalam momenmomen seperti ini sebab ia didoktrin sebagai kekuatan ideologi kolektif untuk melakukan gerakan samar atas nama demokrasi.

Fenomena Post-Truth menghadirkan jenis fakta atas suatu peristiwa yang kebenarannya dapat dimanipulasi sesuai dengan kemauan dan kepentingan pengirim berita. Proses kerjanya sangat terfasilitasi oleh kecanggihan teknologi informasi digital. Dalam konteks alam sosial politik kekuasaan yang saling berebut ruang pengaruh atas penguatan identitas kolektif dewasa ini, fasilitasi teknologi informasi justru memperkuat dan mempercepat penyebaran fenomena Post-Truth sehingga berpotensi dan berpeluang untuk memecah belah sendi-sendi kehidupan masyarakat Indonesia yang sangat multikultur. Terhadap domain ini, sikap bijaksana dan waspada dalam pemanfaatan teknologi digital khususnya media sosial harus disadari sepenuhnya tentang pentingnya merawat dan menghargai perbedaan. $\mathrm{Hal}$ ini kemudian berpengaruh pada cara pandang masyarakat atas pluralisme

\footnotetext{
23. F. Budi Hardiman, "Pentingnya Kebenaran," Kompas, 30 November 2018.

24. Gerung, "Sabung Ayam."
} 
di dalam masyarakat.

Post-Truth menyeruak ke kesadaran publik saat dinobatkan Oxford Dictionaries sebagai word of the year pada November 2016. Kata ini kemudian menjadi populer saat Pilpres AS 2016 dan Brexit pada 23 Juni 2016. Sampai sekarang sering dipakai karena tidak ada rasa percaya atau keyakinan pada data dan fakta ilmiah, ada anti intelektual, penolakan terhadap rasionalitas berpikir, dan kebohongan yang terang-terangan. ${ }^{25}$ Kebohongan yang secara sistematis mengepung ruang publik sampai menuai kepercayaan publik bahwa apa yang mereka utarakan adalah yang sebenarnya. Dalam peristiwa Pilpres AS, dengan terpilihnya Trump menjadikan frase ini kian populer. Karena menurut kubu pemenang Trump, tujuan utamanya adalah menang, jadi kita bohong dulu soal data dan fakta bisa menyusul. Yang terpenting adalah pembenaran dan merasa diri benar. ${ }^{26}$

Ada enam konteks gelagat zaman yang menuntut kebaruan dalam menandai era Post-Truth. Pertama, luasnya akses ke konten informasi berkat digitalisasi komunikasi; kedua, masyarakat bisa membuat informasi sendiri melalui media sosial; ketiga, demokratisasi media dan jurnalisme warga mengkompensasi ketidakpuasan masyarakat terhadap informasi media massa dan kekecewaan terhadap politik; keempat; masyarakat lebih rentan menerima informasi yang keliru karena berkembang komunitas-komunitas se-ideologi dan memiliki keyakinan yang sama; kelima, teknologi telah mengacaukan kebenaran karena viral dianggap lebih penting daripada kualitas informasi dan etika; keenam, kebenaran tidak lagi difalsifikasi atau dibantah, tapi jadi nomor dua. ${ }^{27}$ Gagasan para demagog yang selalu bermain dibalik payung semantik: kebenaran alternatif, fakta alternatif dan ujungnya hoaks.

Dari sudut pandang psikologi, menurut McIntyre, Post-Truth berakar dalam jiwa manusia yang mudah jatuh dalam cognitive bias, prasangka ditingkat pengetahuan yang sifatnya berat sebelah. Manusia tidaklah selalu rasional. Di depan kebenaran yang tidak mengenakkan, manusia cenderung jatuh dalam prasangka yang berat sebelah, dan mencari pembenaran yang membuat nyaman. ${ }^{28}$ Menurut Setyo Wibowo, prasangka bisa muncul karena repetition effect. Menurutnya, para ahli pemasaran paham betul subliminal

25. Lee McIntyre, Post-Truth (Massachusetts: MIT Press, 2018), 1.

26. Bdk. Setyo Wibowo, "Meneropong Bohong à la Post-Truth, Majalah Basis, Nomor 05-06, tahun ke-68, 2019, 2.

27. Haryatmoko, "Mencari Kebijakan di Era Post-Truth: Menghadapi Hoaks, Emosi Sosial dan Populisme Agama," Majalah Basis: Nomor 05-06, tahun ke-68, 2019, hlm. 30, juga dalam Diskusi Publik bertajuk, "Etika Media Sosial di Era Post-Truth dan Disrupsi Informasi," Yogyakarta 12 Desember 2018.

28. McIntyre, Post-Truth, 44-45. 
message yang efektif mempengaruhi perilaku konsumen. Prasangka yang berat sebelah juga bisa muncul akibat source amnesia (lupa pada sumber pasti sebuah informasi). ${ }^{29} \mathrm{Di}$ era melimpah ruahnya informasi seperti harihari ini, orang atau bahkan masyarakat di ruang publik khususnya media daring hampir selalu lupa untuk membedakan sumber yang valid dari apa yang disebut hoaks.

Menurut penulis ada berbagai ragam dan modus secara teknik dalam Post-Truth. Pertama, proses editing foto untuk rekayasa dan memanipulasi citra diri seseorang baik positif maupun negatif untuk menyerang. Kedua, melepaskan suatu pernyataan dari konteksnya, atau dekontekstualisasi untuk memicu emosi sosial publik. Ketiga, menjebak melalui headlines yang penuh sensasi dari isinya yang justru berbeda. Keempat, hujatan untuk memancing kemarahan publik. Kelima, argumen ekstrapolasi, data minim tapi kesimpulan sensasional. Keenam, hiperrealitas digunakan untuk menyembunyikan skenario antar yang fakta dan yang maya.

Ketujuh, weaponisation of information adalah metode retorika yang tidak perlu menyangkal suatu pernyataan agar timbul sikap skeptis. Kedelapan, troll adalah posting pesan jahil untuk memprovokasi massa. Kesembilan, skematisasi adalah upaya untuk menyederhanakan suatu gagasan agar mudah dipahami oleh para pendengarnya, tapi lebih sensasi dan ekstrem untuk provokasi. Kesepuluh, teknik phatique yang menunjukkan bahwa fungsi bahasa bukan hanya untuk menyampaikan pesan, tapi menjaga kontak antara pembicara dan audiens, agar menarik. Kesebelas, menciptakan mitos-mitos tentang pemimpin gerakan berdasar pada etnis, agama, aliran, sekte-sekte tertentu untuk meyakinkan kelompoknya. Kata Arendt, "mereka lalu dengan memberi kualifikasi pemimpin kelompok yang menurut mereka tidak bisa salah." ${ }^{\prime 30}$ Keduabelas, argumen repetisi yakni dengan mengulang-ulang suatu pernyataan sehingga publik percaya. ${ }^{31}$

Hoaks semakin menemukan ruang kebebasannya, ketika manusia masuk dalam kerumunan komunitas yang didoktrin memiliki ego sebagai mekanisme pertahanan diri. Bahwa ketika apa yang kelompok bersangkutan yakini, maka dengan penuh keyakinan pula dilempar ke ruang publik dan memaksa kehendak publik untuk percaya dalam apa yang mereka yakini. Karena setiap individu dalam komunitas secara refleks merasa keyakinan kelompoknya paling benar untuk dipertahankan. Ketika kesalahan yang

29. Wibowo, "Meneropong Bohong," 3.

30. Hannah Arendt, Le systeme Totalitaire (Paris: Seuil, 1972), 192.

31. Bdk. Haryatmoko, "Mencari Kebijakan di Era Post-Truth: Menghadapi Hoaks, Emosi Sosial dan Populisme Agama,' Majalah Basis: Nomor 05-06, tahun ke-68, 2019, hlm. 30, juga dalam Diskusi Publik bertajuk, "Etika Media Sosial di Era Post-Truth dan Disrupsi Informasi," Yogyakarta 12 Desember 2018. 
mereka yakini tersebut terbukti maka ada semacam kenyamanan yang akan terwujud dalam ekspresi backfire effect.

Hoaks juga sangat dipengaruhi oleh tingkat kemampuan orang untuk memahami sesuatu memang rendah. Pada titik ini cognitive bias seseorang mengalami dunning kurger effect..$^{32}$ Persis dari titik ini juga dimanfaatkan oleh kaum elite partai, agama, atau bisnis, untuk memainkan Post-Truth dalam mendominasi psikologi rakyat dengan memancing emosi sosial yang pada ujung kisah akan melahirkan populisme agama dengan alibi demokrasi. Konteks ini semakin mengemuka di saat media konvensional atau peran media tradisional mengalami stagnasi. Sebab, teknologi bisa menjadikan setiap orang jadi pengarang cerita dan isu. Internet sebagai sentralisasi domain digital bagi manusia digital era ini dengan media sosial sebagai jembatan utamanya menjadi trigger untuk hoax, fake news, conspiracy theory.

Dengan melihat konteks peristiwa yang melatarbelakangi di atas, maka menurut penulis, secara kontekstual apa yang terjadi di Indonesia akhir-akhir ini dalam konteks fenomena Post-Truth yakni tiga aspek yang jadi fokus dalam analisis.

Pertama, hoaks. Hoaks pada hakekatnya mengandung tiga unsur yakni informasi yang menyesatkan: antara misinformasi dan disinformasi. Pada dimensi misinformasi; tidak ada unsur kesengajaan sama sekali, tapi persoalannya orang membagikan dan percaya hal itu benar. Sementara disinformasi sebaliknya, ada unsur kesengajaan; orang yang membagikan informasi sudah tahu bahwa informasi tersebut salah atau tidak benar. ${ }^{33}$ Kedua, hoaks terjadi karena di dorong oleh tindakan yang disengaja. Terakhir, hoaks mengafirmasi ketidakbenaran yang ditampilkan seolah-olah kebenaran. Bahwa efek gemilang hoaks yang bertaburan mampu menurunkan derajat rasionalitas dalam ikhwal kita untuk berdemokrasi.

Menurut McIntyre ada empat ragam kebohongan dalam menentukan karakteristik masyarakat Post-Truth untuk menciptakan hoaks. Pertama, kebohongan yang dilakukan karena terdesak setelah melakukan sebuah kesalahan dan mengatakan sesuatu yang tidak benar untuk menutupinya. Kebohongan ini disebut falsehood, bukan penipuan, karena kekeliruan yang tidak disengaja. Kedua, ketidaktahuan yang disengaja, tetapi disebarkan. Orang tidak mengetahui secara benar suatu masalah, tapi tetap ingin menceritakan, tanpa mau memverifikasi apakah benar atau salah. Ketiga, berbohong dengan maksud untuk menipu. Bahwa setiap kebohongan ada audiensnya, arah beranjak dari 'penafsiran fakta' menjadi 'falsifikasi fakta'.

32. Wibowo, "Meneropong Bohong," 3.

33. Bdk. Haryatmoko, "Era Post-Truth dan Prasangka Negatif," dalam Post-Truth dan Anti Pluralisme, ed. Agus Suwignyo (Jakarta: Penerbit buku Kompas, 2019), 9. 
Keempat, berbohong yang melibatkan penipuan diri dan delusi sampai seseorang bisa sungguh percaya sesuatu itu benar bahkan ketika semua sumber yang kredibel mempertanyakannya. ${ }^{34}$

Tom Nichols menegaskan, Internet tak hanya membuat kita semua lebih pintar, tapi juga bodoh. Sebab, internet bukan hanya magnet buat orang yang penasaran, tapi jebakan pula bagi orang yang lugu. Internet mengubah semua orang jadi ahli secara instan. Alih-alih menjadi wadah diskusi cerdas, platform itu justru menjadi tempat pertemuan rentetan pendapat, rumor, ketidakpastian, informasi tak layak, dan diskusi yang tak logis. Orang pun lebih mudah menyerah pada bias informasi ini. Orang hanya mau mendengar informasi yang memang mau didengar. Akhirnya, otak memerintahkan agar manusia mengabaikan suara-suara yang berseberangan dengan keyakinan yang dianutnya. ${ }^{35}$ Demikian berakar kuat atas nama kebebasan dan egalitarianisme. Hal ini didukung dengan populisme masa kini, yang meningkatkan penghinaan atas para elite politik, ekonomi, dan lain-lain.

Sementara demokrasi selalu berpijak pada rasionalitas. Pada puncak rasionalitas adalah kebenaran. Oleh karena itu, dalam demokrasi segala sesutau yang berhubungan dengan rakyat harus dipertanggungjawabkan secara kritis. Hari-hari ini, masyarakat kita berada di ujung kemalasan untuk berpikir, berdialog dan berdialektika. Segala kebijakan dan keputusan dilemparkan begitu saja tanpa ada proses dialektika publik atau verifikasi secara akurat dengan fakta dan data di lapangan. Media hadir sebagai pilar demokrasi modern justru terjebak pada logika waktu pendek. Hanya untuk mengejar target. Media juga berperan penting dalam menghasilkan hoaks. Menunda informasi, media dinilai lambat dan tertinggal. Apalagi media sosial hadir membuat setiap orang tidak bisa menahan diri, karena beramai-ramai berburu like, comment dan share.

Melimpah ruahnya informasi dengan bantuan teknologi digital menjadikan gelombang pembodohan massal yang akan menghempaskan sesama untuk saling curiga. Kita akhirnya hidup dalam suasana untuk saling menjebak dalam kebohongan publik yang secara masif bekerja dalam dunia virtual. Kepalsuan dianggap sebagai kesejatian. Manipulasi dianggap pesona. Rekaan justru lebih meyakinkan publik daripada fakta. Fakta yang berkembang justru dipertanyakan kembali kebenarannya. Karena orang sudah lebih mengikuti keyakinan pribadinya. Dalam hal ini, emosi sosial individu lebih dominan untuk menyakinkan orang lain juga untuk 
diyakinkan oleh orang lain, daripada kepercayaan publik atau fakta lapangan.

Hoaks membuat demokrasi berjalan dalam rel sentimentalis masyarakat yang cenderung bereaksi berdasarkan sentimen-sentimen prinsip identitas, kesamaan ideologi, kepentingan komunitas atau kelompok, serta kaum populis atas nama keyakinan tertentu. Bahaya jurnalisme era digital adalah individu jadi sentralisasi penyalur berita yang mana upaya verifikasi justru diserahkan kepada publik. Tuntutan dan tanggung jawab moral bukan lagi beranjak dari individunya, melainkan datang dari moralitas publik, padahal secara etis individulah penyebar berita sesungguhnya.

Kedua, emosi sosial. Ini adalah iklim sosial politik yang menggeser objektivitas, rasionalitas dan membiarkan emosi sosial publik terjebak dalam banjir hasrat yang punya kecenderungan pada keyakinan meskipun bertolak belakang dengan fakta. Sehingga gerakan masyarakat secara samar mengalami kecenderungan pada doktrin antipluralitas. Model-model gerakan ini mengatasnamakan demokrasi tapi sebenarnya antidemokrasi. Alibi demokrasi sebagai kebebasan berpendapat menjadi argumentasi yang sudah sangat umum dalam perjalanan negara demokrasi. Konteks ini semakin marak karena hadirnya kompleksitas komunikasi digital seperti WhatsApp, Facebook, blog pribadi, SnapChat, Twitter, Line, YouTube dan lainnya. Bentuk komunikasi diatas masuk dalam kategori media sosial yang secara nyata memberikan kebebasan penuh kepada setiap orang untuk jadi otoritas dan tata kelola informasi. Setiap individu akhirnya jadi pusat sekaligus pasar informasi. Yang dalam bahasa media konvensional menyebutnya sebagai jurnalisme warga.

Semua gerakan politik yang berlandaskan pada emosi sosial, sebenarnya mau mendiskreditkan penguasa dengan cara berusaha menggunakan unsur-unsur yang lebih sentimental/emosional daripada yang rasional. ${ }^{36}$ Kaum populisme sangat piawai memakai strategi demagogi dan retorika. Ini adalah model komunikasi yang membidik pengaruh melalui manipulasi. Kelompok ini sangat piawai beradaptasi, menyesuaikan diri dengan situasi emosi sosial rakyat, bahkan sampai mampu menampilkan wajah sebanyak kategori rakyat. ${ }^{37}$ Para praktisi media menyebutnya komunikator demagog sangat mudah mengaduk-aduk emosi massa. Bagi mereka merayu sama halnya dengan mati sebagai realitas untuk menghasilkan tipu daya. "Konteks dan gagasan yang mereka komunikasikan diselipkan melalui nilai,

36. Haryatmoko, "Prasangka Negatif," 8.

37. Ibid., 9. 
opini, serta gagasan." 38

Dalam konteks itu, era Post-Truth menjadi senjata politik disinformasi dan instrumen persuasi massa. Ini merupakan teknik mengolah pesan agar lebih menyentuh emosi sekaligus membungkam pikiran kritis dan analitis masyarakat. Menurut Haryatmoko, sebagai instrumen persuasi, Post-Truth membidik empat hal. Pertama, bentuk rekayasa informasi agar orang bingung menafsirkan realitas. Kedua, manajemen taktik konspirasi dengan membangkitkan kecurigaan dan permusuhan diantara kelompok-kelompok masyarakat. Ketiga, menciptakan mitos-mitos politik. Keempat, self-fullfilling prophecy, ${ }^{39}$ Padahal peramal adalah juga algojonya. ${ }^{40}$ Karena menyasar masyarakat dengan strategi argumen emosional.

Ketiga, populisme agama. Pertanyaan subtilnya, mengapa harus agama? Menurut penulis jawaban kontekstualnya karena agama merupakan ideologi terkuat yang mampu bertahan melintasi zaman. Agama selalu jadi perdebatan sehari-hari. Di saat yang sama agama juga mampu merasuki peristiwa hidup setiap orang akan misteri Yang Maha Kuasa. Ia ditentang juga diterima. Meskipun manusia juga tidak tahu keberadaanya. Bahkan tidak dapat melihatnya. Sebaliknya, semakin ditentang semakin besar pengaruhnya dalam realitas hidup manusia. Semakin ditentang, semakin masuk dalam keyakinan individu, bahkan melampui itu, ikut mengatur detik-detik hidup manusia.

Sejak dahulu populisme agama adalah gejala destruktif karena melakukan "emosionalisasi dan personalisasi politik". ${ }^{41}$ Paling tidak menurut F Budi Hadirman ada dua alasan untuk mengkonfirmasinya. Pertama, politik modern dalam pengertian normatif adalah sebuah proses rasional karena melibatkan argumen dan kepentingan yang dapat dinalar. Populisme naik ke panggung politik justru membawa isu sentimental untuk memancing emosi kerumunan. Kedua, politik itu perkara kepentingan negara, polis. Gerakan populisme menyempitkan politik hanya pada figur pemimpin kelompok tertentu yang berujung pada privatisasi politik pada ruang gerak kelompok tertentu saja. ${ }^{42}$

38. Haryatmoko, “Demagogi dan Komunikasi Politik," Kompas, 25 April 2006.

39. Haryatmoko,"Korupsi dan Tanggung Jawab Politik," Kompas, 7 Januari 2004.

40. Haryatmoko, "Prasangka Negatif," 9, juga dalam Diskusi Publik, "Disrupsi Informasi," Yogyakarta 12 Desember 2018, juga dalam Kuliah Umum LSF, "Emosi Sosial,"

41. Populisme adalah sebuah gerakan yang didasarkan pada emosionalisasi politik karena melakukan provokasi melalui demagogi kebencian serta kemarahan terhadap penguasa dan sistem kemapanan berkedok agama atau keyakinan tertentu. Baca juga, Karin Priester, "Populismus: Historische und aktuelle Erscheinungsformen," Frankfurt: Campus Verlag, 2007, hlm. 12 juga dalam, F Budi Hadirman, "Kebangkitan Populisme Kanan dalam Negara Hukum Demokratis," Majalah Prisma: Vol. 36, No. 3, tahun 2017.

42. F. Budi Hadirman, "Kebangkitan Populisme Kanan dalam Negara Hukum Demokratis," Majalah Prisma 36, no. 3, 2017, 4 . 
Menyetir Sularto, agama merupakan titik awal yang paling mudah meletup karena menjadi jati diri pengikut para pemeluknya, baik dari sisi kosa kata missioner maupun dakwah; sebuah upaya yang dalam sejarah agama apa pun pernah diwarnai dengan kekerasan senjata dalam memperjuangkannya. ${ }^{43}$ Franz Magnis Suseno menegaskan bahwa toleransi agamawi bukanlah relativisme. ${ }^{44}$ Artinya bahwa toleransi bukan berarti membiarkan saja, melainkan lebih dari itu. Seperti apa yang dituliskan oleh FX Armada Riyanto yakni kembali pada jati diri masing-masing sebagai sikap penghargaan pada sesama. ${ }^{45}$

Haryatmoko menegaskan bahwa populisme agama muncul karena sekelompok orang yang memakai jubah agama tertentu secara samar sudah menganggap bahwa demokrasi representasi sudah tidak aspiratif lagi sehingga harus diubah. Dengan itu mereka menamakan diri dalam sebuah jalan perjuangan dengan menjual bendera berbau agama tertentu sebagai satu-satunya keyakinan untuk menempuh jalan kesejahteraan baru. Dengan anggapan seperti itu maka respon kelompok ini kepada pihak penguasa selalu berisi kritikan yang negatif. Diujung fenomena ini, era informasi, gejala ini dicurigai sebagai bentuk demagogi dalam konteks komunikasi politiknya. ${ }^{46}$

Dalam negara hukum modern, yang religius dipisahkan dari yang moral, maka kesalehan religius adalah perkara privat yang tak perlu dibawa ke ruang publik. Mendesakkan konsep partikular tentang perintah Tuhan kepada institusi-institusi publik dihitung sebagai politik sektarian yang dapat mengancam kemajemukan. Namun, sikap mendua akan mengubah kesalehan menjadi kemunafikan. Masalah kesalehan adalah bagaimana yang religius, yaitu yang baik menurut Tuhan, dan yang moral, yaitu yang baik menurut manusia, dapat disatukan sekaligus dalam satu ide. Perintah Tuhan memiliki kebenaran final, tetapi pemahaman manusia atasnya tak pernah selesai, juga tergantung interpretasi aliran-aliran, denominasi-denominasi, sekte-sekte. Jadi, sebaiknya rileks saja agar tetap sehat dalam beriman. ${ }^{47}$

Dalam pandangan Georg Betz dan Carol Johnson, keduanya menawarkan bahwa populisme agama muncul untuk menjawab tiga hal yakni:

43. St Sularto, "Pluralisme dan Toleransi, Keniscayaan Hakiki," dalam Post-Truth dan (Anti) Pluralisme: Forum Mangunwijaya 2018, ed. Agus Suwignyo (Jakarta: Penerbit Buku Kompas, 2019), 25.

44. Franz Magnis Suseno, "Toleransi dan Budi Luhur," dalam Meluhurkan Kemanusiaan:kumpulan esai untuk A. Sudiarja, ed. F. Wawan Setyadi (Jakarta: Penerbit Buku Kompas, 2018), 85.

45. FX Armada Riyanto CM, Relasionalitas. Filsafat Fondasi Interpretasi: Aku, Teks, Liyan, Fenomen (Yogyakarta: Penerbit Kanisius, 2018), 5.

46. Haryatmoko, "Refleksi Filosofis Terhadap "Populisme Agama" Pasca Reformasi" (Seminar Nasional 50 Tahun Fakultas Filsafat UGM, 22 Desember 2017).

47. F. Budi Hadirman, "Kesalehan dan Kekerasan, " Kompas, 6 Januari 2017. 
pertama, apa yang salah atau tidak beres dalam masyarakat? Kedua, siapa yang bersalah? Ketiga, apa yang harus dilakukan untuk memulihkan situasi ${ }^{48}$ Ini menandai reaksi terhadap anggapan kelompok bahwa demokrasi sudah tak berfungsi lagi. Sehingga mampu membangkitkan ketegangan dan permusuhan yang berujung pada perebutan kekuasaan. Yang paling berbahaya ketika agama dijadikan kapital sosial yang memikat sembari memberi legitimasi simbolik untuk menyekat ruang publik kekuasaan sekaligus membuka ruang bagi peluang untuk merebut kekuasaan.

Dalam bukunya, Dominasi Penuh Muslihat: Akar Kekerasan dan Diskriminasi, Haryatmoko dengan sangat dalam menganalisis bahwa ada tiga aspek yang menjadi kunci sukses populisme agama. Pertama, mampu memberi kepastian, maksudnya dalam ketidakpastian ekonomi global, pengangguran dan ketidakadilan. Sejalan dengan ini kaum populisme agama menjanjikan ekonomi adil dan persaudaraan sejati melalui revolusi moral. Agama jadi jaminan akan keyakinan, lalu simpul kepastian. Kedua, agama menumbuhkan keyakinan orang berada dalam kontak dengan makna yang terdalam dalam hidupnya. Ketiga, acuan ke tujuan terakhir hidup memberi pembenaran dan sikap kritis terhadap tatanan yang ditolaknya. ${ }^{49}$

Pada titik ini, Post-Truth menjadi resep mujarab untuk mendominasi politik dalam bentuk supremasi agama tertentu sebagai doktrin ideologi, dimana para pemeluknya dipaksa untuk percaya pada keyakinan individu dan kelompok tanpa peduli ada bukti atau fakta atas kebenaran. Paling tidak, menurut Haryatmoko, ada tiga situasi yang mempengaruhi yakni suatu devaluasi kebenaran berlangsung sebagai dampak dari narasi politisi penebar demagogi, banyak orang atau kelompok merasa nyaman dengan informasi yang telah dipilih, dan media lebih menekankan sensasi yang spektakuler. ${ }^{50}$ Kecenderungan inilah yang menimbulkan bertebaran hoaks, hingga timbulnya emosi sosial yang berujung pada kebangkitan populisme atasnama agama tertentu. Beranjak dari nilai-nilai positif yang didoktrin dari agama, para politisi demagog dengan lihai dan licik menciptakan imajiner kolektif bahwa situasi sedang dalam krisis.

Hari-hari ini antara keagamaan dan kebangsaan justru saling bertentangan. Apalagi momen politik menjelang. Semua pemeluk agama bisa terjebak dalam banjir emosi publik untuk menyerang yang lainnya.

48. Georg Betz dan Carol Johnson, "Stemming the Tide: the Nostalgic Ideology of the Contemporary Radical Populist Rigth" dalam Saving the People: How Populist Hijack Religion, ed. Marzouki, Nadia, Duncan McDonell \& Oliver (Oxford: Oxford university Press, 2016), 3.

49. Haryatmoko, Dominasi Penuh Muslihat: Akar Kekerasan dan Diskriminasi (Jakarta: Gramedia Pustaka Utama, 2010), 94-95.

50. Ibid., 93. 
Keduanya terpaut jarak yang jadi domain pemisahan antara sesama warga bangsa ketika pilihan politik berbeda. Disintegrasi bangsa mulai menguak dari domain seperti ini. Agama dimanfaatkan sebagai doktrin untuk membenarkan klaim kebenaran versi kelompok atau komunitas tertentu saja. Mungkin apa yang ditegaskan oleh Yudi Latif bisa dipertimbangankan yakni, komunitas keagamaan bisa jadi tulang punggung integrasi nasional karena kemampuannya mempertautkan keragaman suku dan kelas sosial secara vertikal oleh kesamaan aliran-aliran keagamaan. ${ }^{51}$ Ini sebagai wujud konektivitas dan inklusivitas lintas komunitas masyarakat dalam mengusung moral publik sebagai modal sosial dan modal moralitas berbangsa dan bernegara.

\section{Tantangan bagi Multikulturalisme}

Apa yang terjadi saat ini baik nasional, lokal maupun global, adalah akibat dari lompatan besar kemajuan teknologi informasi yang membawa gerak baru ideologi secara masif lahir di periode yang bersamaan yakni di penghujung kisah abad 20 dan awal mula abad 21. gelombang perubahan yang secara global tersebut mampu membingkai masyarakat dengan goncangan multitude. Capaian kemajuan yang disambut dengan gegap gempita dan euforia sekaligus secara gagap dalam kepasrahan kita mengalami kemunduran peradaban sebab tumbangnya pranata sosial kebangsaan kita yang selama bertahun-tahun kita bangun.

Bahwa berbagai gerakan samar atas nama demokrasi merupakan perlawanan terhadap sistem politik yang dinilai sudah tidak membawa harapan publik, bahwa demokrasi sudah tidak relevan untuk diterapkan karena itu hanya menguntungkan kelompok tertentu. Lebih berbahayanya dalam balutan agama, para populis memprovokasi kerumunan orang, bahwa politik demokrasi bertentangan dengan doktrin ideologi agama. Pada tataran ini, tokoh agama yang menjadi panutan akan jadi pesona dan primadona dalam menciptakan jarak antara pemimpin yang mereka benci dan warganya.

Salah satu ciri mencolok gerakan era Post-Truth adalah perlawanan terhadap elit politik dan pluralitas. Gerakan mereka dilambungkan oleh keyakinan bahwa rakyat, kerumunan yang turun ke jalan, lebih baik daripada elit pemerintah, dan elit politik telah mengkhianati rakyat. Mereka menebar sentimen anti-partai dan menentang politik perwakilan. Dalam hal ini jelas bahwa musuh kaum populis adalah elitisme dan pluralisme. Gerakan ini juga mengancam demokrasi dari dua sisi. Pertama, dari sisi 
sistem politis, gerakan ini mendestabilisasi negara hukum karena dapat menekan parlemen, mendikte pemerintah, atau mengancanm pengadilan dan polisi. Kedua, dari sisi masyarakat warga, mereka meracuni ruang publik dengan berita-berita bohong melalui media sosial, ujaran kebencian, terhadap elit, minoritas maupun para pendatang. Teknologi media memungkinkan penyebaran yang cepat serta provokasi yang masif untuk menjatuhkan wibawa pemerintah. ${ }^{52}$

Bahwa revolusi teknologi mengantar kita pada kehadiran media digital sebagai jalan raya yang serba gratis dan mudah untuk diakses oleh siapapun dan kapan pun. Ia memberikan kebebasan individu sekaligus mengekang, paling tidak dalam dimensi tertentu. Agus Sudibyo dalam bukunya yang baru tahun 2019 dengan sangat kritis menulis, "tak bisa disangkal bahwa media sosial menghadirkan kegembiraan, gairah dan kemudahan baru bagi masyarakat. Sebuah mode interaksi sosial yang sangat mengentak karena mengamplifikas kenikmatan bagi masyarakat yang sangat fantastis. ${ }^{53}$

Bersamaan dengan itu, gelombang globalisasi khususnya teknologi digital, disrupsi teknologi melahirkan semacam cohort atau membuka peluang kepada setiap komunitas etnik, kelompok masyarakat adat, keluarga sekalipun, bahkan kelompok terkecil dalam sebuah pranata sosial mengalami kesadaran akan identitas kultural kolektifnya yang asali. Kesadaran menguak tapi ruang gerak kian menyempit. Karena menguat ke dalam, sangat prinsipil sementara keluar mengalami kerusakan dengan adanya sekat-sekat ikatan kelompok yang berbeda akar identitasnya.

Orang menggunakan media sosial bukan untuk menguatkan empati sosial dan sikap saling pengertian terhadap orang lain, tapi ada selipan rencana jahat yang terpatri disana. Orang menjadikan media sosial sebagai sarana untuk saling menghujat, menghakimi, merendahkan, menfitnah dan saling menyerang. Tanpa sadar teknologi telah memperbudak detik hidup manusia. Ia memberikan kebebasan untuk mengakses, sembari mengendalikan dan mengawasi gerak gerik dan setiap keputusan yang kita ambil. Ketika kita melibatkan diri dalam 'lanskap informasi global, sesungguhnya kita memasuki hidup dalam kerangka panopticon yakni hidup dalam sitem pengawasan dan kontrol yang terintegrasi secara global ke dalam elemen big data ataupun IoT. Persis pada titik inilah, kita menjadi objek surveillance capitalism sedemikian rupa," 54 untuk mudah dan gampang dimanipulasi ke dalam sekat-sekat etnis, keyakinan, selera pasar, semangat primodialisme,

52. Hardiman, "Kebangkitan Populisme Kanan," 6-8.

53. Agus Sudibyo, Jagat Digital: Pembebasan dan Penguasaan (Jakarta: Kepustakaan Populer Gramedia, 2019), 1.

54. Ibid., 4-5. 
provokasi tindakan brutal dan represif seperti terorisme, radikalisme, dan fundamentalisme. Pada konteks ini rasanya perlu sebagai bangsa untuk merumuskan ulang mengenai konsep privasi warga bangsa dan ruang bagi kedaulatan diri.

Sejarah Panjang perjalanan bangsa ini, selalu saja menuai banyak konflik soal identitas. Masa depan bangsa dengan segala kemajuan teknologi yang mengepung hari-hari ini, seolah mau menunjukkan disatu sisi keterbukaan didapatkan, sisi lain penyempitan ruang gerak individu dikapling atas nama identitas tertentu. Ancaman terhadap peradaban bangsa yang beragam dan multukultur sedang dan akan terus melanda bangsa ini. Pluralisme, toleransi dan universalitas menjadi sebuah keharusan yang harus terus digaungkan agar masa depan keberagaman bangsa ini terus bisa kita banggakan. Jalan dialog harus terus diciptakan sebagai sikap hidup sehari-hari, sebagai keterbukaan pada semangat untuk menciptakan rasa damai dengan membiarkan masing-masing kayakinan akan identitasnya tumbuh dan berkembang.

Keprihatinan yang sama dijelaskan oleh Asep Salahudin bahwa, populisme adalah istilah yang begitu problematik dan definisinya tidak pernah menemukan kata sepakat dalam literasi politik mutakhir, kecuali populisme. Kata ini hadir dengan pemaknaan beragam, bahkan terkadang berbenturan satu sama lain. Mungkin seperti bunglon yang memiliki kemampuan mengubah warna tergantung situasi di setiap negara. Populisme juga punya kelenturan melakukan kawin-mawin dengan 'ideologi' setempat berdasar kepentingan yang ada dibelakangnya. Karena populisme mereduksi politik menjadi sekadar personalisasi ketokohan, pada saat yang sama, terjadi pembungkaman kritisisme kawanan pengikutnya. Apa pun yang dikatakan sang tokoh dianggap sebagai kebenaran yang harus diperjuangkan. Walaupun dengan cara menghinakan akal sehat, melabrak aturan, dan menafikan segenap prosedur. ${ }^{55}$

Menurut Sularto, pluralisme umumnya dianggap sebagai given for granted atau taken for granted bangsa ini. ${ }^{56}$ Bahwa dalam segala hal, Indonesia sejak awal sudah plural. Dalam perjalanannya makin tergambarkan soal pluralitas tersebut sebagai bangsa yang multikulturalisme. Beragam tapi tetap satu. Yang mana jalan perjuangan kita kemudian masih berlanjut sampai sekarang ini. Bahkan lebih kompleks lagi karena banyak bertumbuh kembangnya berbagai macam gerakan yang punya maksud dan tujuan berbeda dengan apa yang dicita-citakan bersama. Berbagai macam upaya seperti

55. Asep Salahudin, "Populisme, Bunglon Politik dan PR Jokowi-Ma'aruf," Media Indonesia, 22 Oktober 2019.

56. St Sularto, "Keniscayaan Hakiki," 22. 
separatisme sebagai antithesis, untuk mau memisahkan diri dan mencari bentuk ideal baru sebagai komunitas bangsa dengan cita-cita tunggal atas identitas tertentu justru secara otomatis akan melawan realitas peradaban yang sudah jelas-jelas terbukti yakni bangsa yang multikultur.

Belakangan ini media sosial penuh dengan pengkhotbah agama. Tentu itu perkembangan yang positif. Namun, ketika agama dipelintir dan dimanipulasi semata untuk cuci otak masyarakat, itu juga termasuk hoaks karena menyembunyikan niat yang tidak tulus. Kemuliaan agama direduksi. Lewat jendela gawai, kita diajak memasuki labirin gosip politik yang serba remang-remang, pengap, dan tidak mendidik. Realitas dunia yang luas, kompleks, dan indah diperas selebar gawai yang telah "di-framing" sehingga kita terputus dari dunia yang otentik dan empiris lalu masuk ke pelataran Post-Truth. Kita heboh memperdebatkan pseudo-kebenaran. ${ }^{57}$

Sehingga intoleransi, gerakan represif seperti radikalisme, terorisme, fundamentalisme merupakan tantangan serius bangsa ini jauh di depan sana. Homogenitas adalah keadaan aktual. Fenomena antipluralisme akhirakhir ini seolah akan mengantarkan kita kembali pada riak-riak yang dulu sudah dianggap selesai ternyata muncul kembali. Sekarang setelah 20 tahun lebih reformasi kita seolah maju selangkah mundur selangkah. Bahwa kenyataan sejarah demikian ruwet karena sedang pada persimpangan jalan, kita mau maju tapi kebingungan mau ke arah yang mana. Kita selalu terjebak pada kebesaran masa lalu hingga gagap dengan gelagat global yang datang mengepung peradaban bangsa kita.

Bahwa ada dan menguatnya politisasi agama tertentu melalui aksi populisme dengan gaya demagogi untuk memprovokasi masyarakat serta sosialisasinya di ruang publik, sebenarnya mereka mau menegaskan bahwa primodialisme atau dalam bahasa yang lebih sederhana "prinsip identitas" masih memiliki peran dan geliat polarisasi yang selalu mempesona baik bagi demagog dengan gaya demagoginya maupun simpati dari para pengikutnya masih menempati posisi penting dalam demokrasi Indonesia kontemporer.

Lalu, bagaimana menatap perjalanan demokrasi ke depan dengan karakteristik bangsa kita yang multikultur?

\section{Mengarungi Demokrasi, Memaknai Keragaman Identitas}

Mungkin pertanyaan mutakhir hari-hari ini adalah apakah demokrasi bisa akan terus tumbuh dan bertahan dalam keragaman etnik sekaligus keseragaman etnik, agama, dan ideologi? 
Indonesia, masa lalu hingga hari ini, masih saja diterpa berbagai isu yang berpotensi memecah-belah. Tidak ada lagi suasana guyub dan keakraban yang sebenarnya menjadi tradisi bertahun-tahun bangsa ini. Semua orang terjebak dalam emosi sosial untuk saling menjaga jarak. Ruang gerak antar sesama kian tersekat oleh ujaran kebencian, terhimpit oleh prinsip identitas, dan terpisahkan oleh doktrin agama sebagai ideologi. Basis isu hoaks bermula dari gejala sosio kultural seperti ini.

Sebagaimana kita memperoleh kemerdekaan, demokrasi tidak diterima atau diperoleh melalui serah terima jabatan diantara kaum aristokrasi, elitisme atau pendiri bangsa ini. Ia terlahir dan diperoleh melalui perjuangan gelombang debu, asap, keringat dan airmata. Semua ini tentu memakan korban yang tidak mudah untuk dibayar, sebab dalam perjalanan perjuangan mewujudkan negara demokrasi cita-cita kebebasan dan kesetaraan menjadi mimpi abadi.

Wasisto Raharjo Jati, mengatakan romantisasi "demos" menjadi kata kunci yang menarik untuk mengembalikan nilai-nilai subtantif demokrasi ke dalam praktik politik pemerintahan. Namun, dalam aspek lain, populisme secara tidak langsung mereduksi marwah demokrasi karena bertujuan menelikung saluran konstitusional dengan "menafikan" berbagai macam tahapan dan prosedur yang seharusnya dilalui. Hal ini tentu menjadi preseden negatif bagi indikator pencapaian demokrasi suatu negara dengan ketidakpercayaan terhadap lembaga-lembaga publik mengindikasikan adanya permasalahan kredibilitas dalam relasi negara dan masyarakat. Hal inilah yang mendorong gerakan kaum populis dalam dua sisi yakni aksi kuratif sekaligus aksi represif terhadap demokrasi. ${ }^{58}$

Cas Mudde dalam Setyo Wibowo, 2019 memberikan definisi minimalis ihwal populisme, 'sebagai sebuah ideologi (nantinya diperjelas sebagai thin-centered ideology sebuah ideologi mengambang) yang menganggap bahwa masyarakat terbagi secara homogen dan antagonis menjadi dua bagian: rakyat murni versus kaum elite yang busuk, dan ideologi ini beranggapan bahwa politik mestinya perwujudan dari volonte generake/kehendak umum rakyat' dan 'populisme bukanlah sebuah ideologi yang ketat, dan bukan pula ideologi yang longgar dan terbuka. Sebagai ideologi mengambang, populisme memiliki semacam world view, tetapi tanpa memberikan distingsi yang secara intelektual bisa diargumenkan dengan kokoh' ${ }^{59}$

58. Wasisto Raharjo Jati, "Trajektori Populisme Islam di Kalangan Kelas Menengah Muslim Indonesia," Majalah Prisma 36. No. 3, tahun 2017, 19-27.

59. A Setyo Wibowo, "Populisme di Tangan Demagog," Majalah Basis, Nomor 05-06, tahun ke-66, 2017, 2-3, juga dalam "Populisme: Ideologi Mengambang," Majalah Basis, Nomor 07-08, tahun ke-68 2019, 3-5. 
Ruang demokrasi hari ini, sangat memberikan kebebasan setiap orang untuk mengekspresikan pikiran dan perasaannya dalam medium yang luas melalui gawai berbasis internet. Membicarakan politik yang cerdas dan etis itu bukanlah utopia bagi kita karena dulu bangsa ini pernah memiliki politisi-intelektual yang selalu menjaga standar etika yang tinggi. Politisi seperti Soekarno, Hatta, Nasir, Roem, Soekiman, Agus Salim, dan teman-teman seangkatannya yang berpolitik secara cerdas dan bermartabat. Mereka berbeda agama dan ideologi, tetapi tidak mau menebarkan hoaks dan fitnah untuk menjatuhkan lawan. ${ }^{60}$

Hari-hari ini, begitu banyak gerakan samar atas nama demokrasi mewarnai ruang publik kehidupan bangsa kita. Atas nama kebebasan berpendapat sebagai dalil negara demokrasi, justru jadi alibi untuk melakukan berbagai tindakan penghinaan, saling serang, membenci, sembari membuat pembedaan. Semua itu hadir dengan tameng demokrasi. Kebebasan akhirnya tak terkendali yang justru berakibat pada rasa saling curiga antar para elit, lalu merambat ke warga bangsanya. Fakta suatu peristiwa tidak diakui lagi, justru dipertanyakan dengan membangun persepsi baru ke publik. Berseliweran berita bohong, bertaburan bualan hoaks berupa mitos.

Demokrasi memang selalu paradoks. Selalu hangat untuk diperbincangkan. Kalau Fukuyama bilang "berakhirnya sejarah" menurut penulis justru perdebatan abadi. Karena antara kepastian dan ketidakpastian selalu berujung pada pilihan untuk memilih. Entah menang atau kalah. Menurut Boni hargens, demokrasi memang paradoks sebab ia memperjuangkan kebebasan sekaligus membunuh kebebasan. Ia membicarakan kebenaran sekaligus mewartakan bualan. Berbicara keadilan sekaligus mengekalkan ketidakadilan. Setidaknya, begitulah modus vivendi (cara hidup) demokrasi. ${ }^{61}$

Hari-hari ini paradoks itu kasatmata. Diperlihatkan secara nyata. Ingatlah, menjelang pemilu, semua partai politik menabur spanduk antikorupsi, nyatanya para kadernya tetap candu untuk korupsi. Berteriak perang melawan isu primodial, nyatanya ekspresi SARA tetap mewarnai panggung demokrasi. Mereka menekankan fakta dan kebenaran, nyatanya bualan berupa mitos. Konteks demikian semakin ruwet ketika mulai tahun 2011-an ide-ide radikal diambil ahli oleh kaum ekstrem kanan. Bahkan penolakan terhadap sains dan kebenaran, anti-intelektualisme sebagai awal kekuasaan kelompk tersebut yang berhasil mengambil ahli wacana posmodernisme.

\footnotetext{
60. Komaruddin Hidayat, "Hoaks dan Agama," Kompas, 8 Januari 2019.

61. Boni Hargens, "Sensasi dan Demokrasi," Kompas, 9 April 2013.
} 
Dari semua latar belakang isu, opini publik serta berbagai gerakan yang mengancam integrasi bangsa adalah tanggung jawab sejarah bagi kita sebagai bangsa yang sudah mengalami masa kolonialisme hingga menikmati kemerdekaan hingga 74 tahun. Tema dan konsep pembangunan pun kita usung "SDM unggul, Indonesia maju" Tentu ini visi besar dan jalan panjang proses kita sebagai bangsa dan negara yang matang dan dewasa dalam membangun masa depan demokrasi kita.

Menurut F Budi Hadirman, demokrasi kita hari-hari ini sedang dalam krisis tiga aspek kebenaran sebagaimana dianalisis oleh filsuf kontemporer, Jürgen Habermas, yakni kebenaran sebagai fakta, sebagai moralitas, dan sebagai autentisitas. Pertama adalah bahwa ide demokrasi itu sendiri mengandaikan kebenaran sebagai fakta. Demokrasi adalah pemerintahan oleh rakyat. Kedua, kebebasan berpendapat dalam demokrasi merupakan sebuah ide moral. Kebebasan tidak akan kita miliki jika kebebasan kita diancam oleh kebebasan orang lain. Sebagai ide moral kebebasan menjadi berlebihan jika dipakai untuk membohongi publik atau untuk membenci pihak lain. Demokrasi yang sehat tidak menoleransi intoleransi yang dicetuskan dari kebebasan berpendapat. Ketiga, demokrasi pada hakikatnya adalah komunikasi, dan komunikasi perlu dilandasi kepercayaan timbal balik. Kepercayaan tersebut baru mungkin didapat kalau ada kebenaran sebagai ketulusan. Integritas para politikus dan transparansi publik sangatlah sentral untuk membangun iklim kepercayaan dan respek timbal balik. Politik Pasca-Kebenaran berbenturan dengan kodrat demokrasi. Retorika narsistis yang disebarkannya membelah para pemberi suara menjadi kawan dan lawan. Hal itu meningkatkan iklim ketidakpercayaan timbal balik dan potensi kekerasan. ${ }^{62}$

Oleh karena itu, inovasi, kreativitas dan strategi transformasi perlu segera dipersiapkan. Pendidikan sebagai "gerak kontekstualisasi"63 terhubung dengan berkembangnya keterbukaan setiap insan bangsa pada realitas dunia, ketidakpastian, dan imajinasi. Harus ada penegasan pada pentingnya partikularitas tanpa meninggalkan kesadaran pada humanitas transendental sebagai dimensi universalitas nilai. Karena konteks hidup manusia dalam merespon perkembangan zaman selalu bersifat partikular, tapi soal aspek kemanusiaan tidak bisa jauh dari konteks sosial budaya sebagai kekayaan lokalitas yang menjadi modal utama kebudayaan dalam melintasi zaman. "Pada konteksnya yang partikular itu pula, manusia tumbuh dan bergerak dengan bahasa kehadiran yang khas serta berakar

62. Hardiman, "Pentingnya Kebenaran."

63. In Nugroho Budisantoso SJ, "'Menyimak Kembali Gagasan Y.B Mangunwijaya, Pr,'” dalam PostTruth dan (Anti) Pluralisme, ed. Agus Suwignyo (Jakarta: Penerbit Buku kompas, 2019), 160. 
pada lingkungan sosial-budayanya." 64

\section{Langkah-langkah Masa Depan}

Pertama, Pendidikan karakter. Kita harus punya gagasan yang kompeheresif dalam mendaur ulang sistem pendidikan kita. Transformasi menjadi harga mati untuk segera dilakukan. Maksudnya adalah bagaimana menjelaskan berbagai aspek pengajaran dan pembelajaran bagi perkembangan personal. Pendidikan karakter meliputi beberapa area, seperti: penalaran moral, pembelajaran sosial dan emosional, pendidikan/kebajikan moral, pendidikan keterampilan hidup, pencegahan kekerasan, dan resolusi konflik.

Kedua, pendidikan agama harus fokus pada sosiologi agama. Masyarakat di negeri ini sekarang dipenuhi dengan ketegangan antarkelompok yang luar biasa: antarkelompok politik, kelompok etnik, kelompok keagamaan - antar dan intra-agama - dan sebagainya. Saatnya beralih dari dimensi teologis ke dimensi sosiologis, dari hanya sekedar menafsirkan ke praktek hidup baik bersama. Seperti kata Haidar Bagir bahwa pengembangan pendidikan agama yang menekankan pada keberagaman dan keterbukaan, serta pengembangan daya kritis dan kemampuan literasi media sosial. ${ }^{65 \prime \prime}$ Agama jangan direduksi hanya sebagai ideologi." 66

Ketiga, strategi kebudayaan. Kemajuan teknologi telah merangsek akar budaya negeri ini, rasanya perlu kita bekerjasama untuk kembali pada titik simpul dimana kita lahir dan bersatu sebagai bangsa yakni rumusan dan strategi kebudayaan yang sebenarnya sudah dirumuskan secara kompeherensif di tahun 2017, sekarang bagaimana mengimplementasikan semangat tersebut dalam peristiwa hidup. Budaya sebagai akar menciptakan manusia spiritual, manusia moral, manusia estetis, dan manusia yang sadar dan berpikir. Ia berakar pada nilai-nilai kemanusiaan paling dalam, sebagai makhluk sekaligus pengejawantahan ketuhanan, sebagai bagian dari persaudaraan kemanusiaan, bahkan persaudaraan kemakhlukan, yang cirinya adalah memiliki fitrah cinta kebenaran, kebaikan, dan keindahan. "Budaya adalah sumber keutuhan dan integritas kehidupan manusia, belajar bagaimana menjadi manusia otentik."'67

Keempat, perlu memperkenalkan media literasi di sekolah, dengan formulasi penerapan yang disesuaikan dengan tingkat pendidikan masing-masing. Dengan itu, generasi mudah kita perlahan memahami

\footnotetext{
64. Ibid., 160 .

65. Haidar Bagir, "Agama di Era Revolusi 4.0," Kompas, 10 Oktober 2019.

66. Haryatmoko, "Agama : Etika Atasi Kekerasan?," Kompas, 17 April 2000.

67. Haidar Bagir, "Negeri Tunabudaya," Kompas, 9 Januari 2016.
} 
mekanisme, teknik dan trik media sosial agar tidak mudah di manipulasi. Sebab, adagium modern era digital adalah semua orang jadi sumber berita sekaligus pewarta bagi dirinya dan masyarakat. Pengembangan minat dan daya baca, yang memungkinkan menambah kekayaan sumber informasi, adalah salah satu langkah yang mutlak dalam konteks ini.

Kelima, membiasakan dengan fact-checking agar tidak menjadi bumerang. Kebiasaan untuk memeriksa dahulu setiap berita atau informasi yang beredar. Mengutip Setiaji Setyo Nugroho, periksalah dulu sumber berita dengan cara meneliti alamat situsnya, detil visual; iklan yang terlalu banyak patut dicurigai; perlu dicek redaksinya, apakah bisa dikomplain atau tidak; apakah memiliki ciri-ciri pakem media; dan perlu dicek ke media mainstream; apakah memberitakannya atau tidak; bisa digunakan juga Hoax Buster Tools. ${ }^{68}$

Keenam, pahamilah siapa yang mengatakan sesuatu ke publik. Ini persoalan ketokohan seseorang yang memang didukung oleh banyak faktor baginya untuk berbicara di ruang publik sebagai seorang tokoh. Karena kebenaran faktual selalu di dukung oleh epistem sikap objektif seorang pakar atau ahli yang berpengalaman dalam mendalami suatu masalah melalui riset yang konsen dan fokus pada kedalaman persoalan.

Ketujuh, upaya untuk verifikasi secara ketat terhadap inkonsistensi suatu laporan dengan mencek otentisitas informasi apakah sungguh demi kebaikan publik juga kepentingan umum. Ini peran strategis yang perlu keterlibatan otoritas media. Maka menurut Ashadi Siregar, perlu dipertajam kriteria kelayakan dalam mencari fakta di ruang publik. ${ }^{69} \mathrm{Di}$ sinilah peran pemerintah sebagai pengendali utama dengan kerjasama bersama masyarakat perlu digerakkan secara konsisten dan komitmen pada netralitas jurnalisme dalam mendidikan warganya.

Kedelapan, jurnalisme digital perlu penekanan pada etika komunikasi dalam hal fasilitasi perkembangan cerita, berita dan informasi yang benar untuk bisa mengendalikan sentimentalisme. Perubahan media cetak ke digital, bukan hanya masalah teknologi semata tapi kita sedang mengalami krisis etika profesionlisme soal kebenaran dalam membagikan informasi dan mudah menerima kebohongan yang diterima. Soal ini perlu diketahui juga bahwa hoaks juga dijadikan modus bisnis kaum kapitalis yang terintegrasi secara global.

Kesembilan, menekankan pentingnya etika media. Sebagai pilar utama demokrasi era digital, media perlu merumuskan etika bersama dalam

68. Setiaji Setyo Nugroho, "Hoax dan Media Sosial" (Ceramah di Universitas Ciputra Surabaya, 10 Maret 2018).

69. Ashadi Siregar, "Media dan Politik Pasca-Kebenaran," Kompas, 26 Oktober 2019. 
menyambut realitas keberagaman yang kian kompleks dengan proses digitalisasi. Setiap media kiranya diperketat soal objektivitas dalam menerbitkan berita dan informasi dengan metode pelatihan berkelanjutan agar jurnalis bersikap secara bijaksana dalam mengedepankan kultur nilai bagi kepentingan bersama.

Kesepuluh, penegakkan hukum yang tegas dan adil. Kita selama ini, selalu mengklaim sebagai negara hukum tapi penegakkan hukum selalu tidak mendapat kejelasan. Hukum sebagai panglima harus tegas dan menjamin kebebasan individu bagi kebebasan publik, tanpa harus mengorbankan sesama. Maka, harus tetap dalam bingkai konstitusi dan pemeliharaan HAM, pemerintah perlu mengambil tindakan lebih tegas dalam menerapkan aturan-aturan yang berlaku. Yang tak kalah penting adalah pengembangan pendidikan agama yang menekankan pada keberagaman dan keterbukaan, serta pengembangan daya kritis dan kemampuan literasi media sosial.

Kesebelas, mempersiapkan ruang bagi generasi milenial untuk berkumpul membangun klaster-klaster kreatif sesuai bakat dan minatnya. Dalam hal ini, menciptakan komunitas-komunitas sosial masyarakat yang kreatif atau konsep-konsep rekayasa sosial. Dalam pengalaman banyak bangsa (asal kita mau merenungkannya), segala perkara dunia tidaklah dibagi antara yang susah dan yang mudah, melainkan oleh apakah solusinya sesuai yang diminta sejarah atau tidak. Jika sesuai jadi mudah, jika tidak sesuai jadi susah. "Kerja pokoknya bukan saat berretorika atau menyusun peta jalannya, namun membangun jejaring Brain Power dan Community Power. Proses mengawinkan kedua domain ini, setidaknya kita harus menciptakan ruang untuk saling bicara dan bekerja sama dalam mencerdaskan dan menajamkan masyarakat, seperti pejabat publik yang berpikir progresif disruptif, pendidik dan wirausahawan sosial (social entrepneurs)."

\section{Kesimpulan}

Akhirnya, upaya pencarian identitas sebagai jalan keluar atas berbagai gerakan antipluralisme pada hari-hari ini akan menemui kesulitan apabila kita tidak bisa menempatkannya pada partisipasi dalam menjalin kerjasama lintas etnis ataupun multikulturalisme agar bisa bersama-sama memahami kompleksitas dan dinamika perkembangan teknologi digital. Teknologi maju dan canggih, tapi tidak bisa menciptakan manusia untuk jadi pribadi berkarakter dan bersikap secara bijaksana. Secanggih apapun teknologi, manusia tetap jadi pusat peradaban zaman. 
Tak lama lagi semua orang di bumi akan terhubung. Dalam sepuluh tahun mendatang, penduduk dunia maya akan melampui jumlah penduduk bumi. Praktis setiap orang diwakili dengan berbagai cara di dunia maya, membangun komunitas yang aktif menurut minat masing-masing, serta mencerminkan dan memperkaya dunia nyata kita. Jauh melampui itu, kita akan berhadapan dengan kehadiran big data yakni semua orang akan terekam ke dalam lanskap informasi global. Persis pada konteks ini, identitas pribadi seseorang mengalami pergeseran bahwa media sosial hadir sebagai medan pengakuan sosial baru. ${ }^{71}$

Transformasi digital seperti tercermin dalam derasnya penetrasi layanan media sosial, mesin pencari, dan situs e-commerce, pada gilirannya telah menampakkan diri sebagai sebentuk aporia. Ia menawarkan pembebasan, sekaligus memendam intensi penguasaan. ${ }^{72}$ Ia menyajikan kemungkinan deliberasi, sekaligus memperlihatkan tendensi instrumentalisasi. Ia melahirkan peluang-peluang menjanjikan pada aras ekonomi kreatif, sekaligus menciptakan struktur kapitalisme baru yang memusatkan surplus ekonomi digital global. Post-Truth bekerja dalam domain ini.

Melalui tulisan sederhana ini penulis mencoba untuk menawarkan perspektif kritis tentang fenomena digitalisasi ketika pada umumnya publik bersikap positivistik dalam memandang fenomena tersebut. Penulis mencoba meneropong dimensi-dimensi "antidemokrasi" melalui tiga fenomena aktual yakni hoaks, emosi sosial dan populisme agama yang mana fenomena digitalisasi telanjur lekat dengan demokratisasi. Sebab era ini harus menekankan perlunya keseimbangan perspektif dalam menelaah revolusi digital, positivistik, maupun kritis. Dalam konteks ini, integrasi suatu negara ke dalam lanskap informasi global membawa pengaruh positif sekaligus dampak destruktif.

Post-Truth hadir dalam beragam kompleksitas penetrasi arus globalisasi yang menakjubkan juga mematikan. Fenomena ini dalam istilah para peneliti filsafat teknologi menyebutnya world polygamy yang berarti kita hidup dalam banyak dunia. Problem identitas bahkan masuk sampai titik temu antara komunitas. Maksudnya teknologi membuka ruang bagi komunitas terkecil sekali pun untuk mengkapling atau mengeksklusifkan diri hanya dalam grup keluarga tertentu. Gejala ini sudah tampak dan terasa hari-hari ini. Keterbukaan informasi justru mengekang orang dalam identitas yang kian sempit seperti grup keluarganya, komunitas sosialnya, organisasinya, institusinya dan sebagainya.

71. Schmidt \& Cohen, Era Baru Digital, 23-4.

72. Sudibyo, Jagat Digital, 159. 
Dalam konteks demikian, era Post-Truth memberi pesan bagi manusia universal untuk bersikap arif dan bijaksana dalam memainkan perannya di dunia yang penuh disrupsi teknologi. Karena, dalam ketakjuban menggunakan aksebilitas teknologi yang sangat gampang dan mudah, sebenarnya mau menyeret sekaligus menjebak kita dalam ruang gerak yang terbuka dan bebas tapi kebingungan bahkan hampir tidak bisa membedakan mana lawan atau kawan, lebih dari itu kita kesulitan merangkul mana kompetitor dan mana kolaborator.

Pada akhirnya kita perlu kerjasama. Konektivitas membantu aksesibilitas dan akselerasi. Sementara kolektivitas membantu mobilitas dan jejaring. Sebab, bukan hanya konektivitas juga kolektivitas. Simpul perekat antara keduanya tampak dalam dasar negara kita yakni Pancasila. 